\title{
Factors Contributing to the Success of Ethnic Restaurant Businesses in Canada
}

\author{
Phuong Nam Le1, Charles R. Needham ${ }^{2}$ \\ ${ }^{1}$ University Canada West, Vancouver, BC, Canada \\ ${ }^{2}$ Walden University, Minneapolis, MN, USA \\ Email: lpnam@hotmail.com
}

How to cite this paper: Le, P.N. and Needham, C.R. (2019) Factors Contributing to the Success of Ethnic Restaurant Businesses in Canada. Open Journal of Business and Management, 7, 1586-1609. https://doi.org/10.4236/ojbm.2019.74110

Received: July 8, 2019

Accepted: August 10, 2019

Published: August 13, 2019

Copyright () 2019 by author(s) and Scientific Research Publishing Inc. This work is licensed under the Creative Commons Attribution International License (CC BY 4.0).

http://creativecommons.org/licenses/by/4.0/ (c) () Open Access

\begin{abstract}
Due to the small size of their businesses, small business owners often face a high failure rate. Within the first 7 years since opening, more than half of small businesses seek to close its operation. The author of this qualitative multi-case study examines the factors contributing to the success of small ethnic restaurants owners to remain operable beyond 7 years. The owners of three small ethnic restaurants that have been operating for more than 7 years in Metro Vancouver, British Columbia, Canada were selected for this study. The author interviewed the owners and conducted an examination of available physical artifacts including locations, premises, websites and social media pages. Five factors were identified: hard work, passion, family support, location and quality of food and services. Those factors determine the success of small business. The findings of this paper will help current and future small ethnic restaurant business owners to improve their business performance and survival rate.
\end{abstract}

\section{Keywords}

Small Restaurant Business, Small Business Successful Factors, Small Business in Canada

\section{Introduction}

Small businesses account for a significant portion of the Canadian economy [1]. In 2012, the country had 1.08 million small businesses, $98.2 \%$ of all Canadian businesses. Small business leaders' contribution is $41 \%$ of the total private sector Gross Domestic Products (GDP) in 2008. Furthermore, small business is the major source of job creation in Canada. In 2012, 7.7 million employees were working for small businesses. On average, from 2002 to 2012, Canadian small 
businesses have more than 100,000 new jobs open each year [2]. Despite the significant contributions to the national economy, small businesses in Canada have numerous challenges [1]. Small businesses have limited resources, knowledge, and market power because of the small size [3]. Thus, the survival rate among small businesses is low. Less than one-third of new small businesses will survive after a decade [2]. Moreover, Macdonald noted most small businesses in Canada fail within the first 7 years after start-up [4]. Consequently, business failures might increase the unemployment rate and negatively affect the country's economy. The objective of this study is to explore the factors that make small business success or failure.

The public and leaders in government bodies across Canada recognize the importance of small businesses for national prosperity [5]. Small business owners contribute significantly to the local community and the Canadian economy in general [6]. Approximately $25 \%$ to $41 \%$ of Canada's GDP comes from small businesses [2].

Small business leaders are creating jobs for the community, paying taxes toward government revenue, expanding tourism, improving diversity in Canadian culture, and providing funding for local charities, community organizations, and projects [5]. However, small businesses have more disadvantages than larger businesses, such as access to financial resources, business information, and international customers [7]. In addition, many small business managers lack general management skills such as marketing and financial management [8]. Consequently, the failure rate among small businesses in Canada is high [2].

The failure rate among Canadian small businesses is high despite the important contributions to the Canadian economy [3] [9]. Small businesses account for $98.2 \%$ of all businesses in Canada. Although small business owners employ $69.7 \%$ of the total labor force within the private sector [2], and of this number, only $27 \%$ of small businesses survive after the first 7 years [4]. The general business problem is small ethnic restaurant owners who do not adopt successful operational strategies may struggle with business sustainability [10] [11]. The specific business problem is some small ethnic restaurant owners lack strategies to remain operable beyond 7 years.

The purpose of the qualitative multi-case study was to explore strategies small ethnic restaurant business owners use to remain operable beyond 7 years. The population for this study was small ethnic restaurant business owners in British Columbia, Canada. This population was appropriate for the study because small ethnic restaurant owners in British Columbia might reflect all small ethnic restaurant owners across Canada. The result of the study is a guidance for small business owners or potential business owners in the ethnic restaurant service industry to improve the business success rate. The small business owners might learn from successful business owners and apply the knowledge to business practices. As a result, the performance of small business owners might improve, and the unemployment rate may decrease. Furthermore, because small businesses owners contribute significantly to the national GDP, successful small 
businesses positively influence the national economy. As a result, people living standards might improve [12].

The central research guiding this study is what strategies did small ethnic restaurant business owners employ to remain in business after 7 years? I collected data by conducting face-to-face interviews and examining the available physical artifacts of the businesses.

\section{Significance of the Study}

The results of the study are an important contribution to current business practice of small ethnic restaurants. The owners can use the knowledge from the study to formulate sound strategies for the businesses. First, the results of the study may contribute to the reduction of gaps in the current literature, which may add to the body of knowledge on small business management. Other small ethnic restaurant business owners, with adequate understanding of the successful factors, might find success by improving better management practice in the future.

Second, small ethnic restaurant business leaders and policy makers in Canada may find the results of the study valuable. The results of the study may explain the potential influencing factors on small ethnic restaurant business performance. Therefore, through the study, I might provide vital information for major stakeholders of new start-up small ethnic restaurant businesses and government policy makers [13]. The ethnic restaurant owners may recognize the level of influence from the elements on ethnic restaurant business operations. Teng, Bhatia, and Anwar noted business leaders might make better management decisions based on the understanding of the main reasons for success or failure [14]. The owners may learn and apply better practice from the successful businesses. Consequently, the survival rate among small ethnic restaurant businesses in Canada might increase.

The small business sector is a critical component of the Canadian economy [5]. Small business owners employ a substantial portion of the private labor force in Canada [4]. Moreover, a significant portion of the country's GDP comes from small businesses [2]. The contributions of small ethnic restaurant business owners are also significant to small businesses and the economy [10] [15]. Thus, the success of small ethnic restaurant businesses is vital for the prosperity of Canadian society.

Small ethnic restaurant business owners might acquire strong knowledge on the elements that may make the businesses succeed or fail from the study. Knowledge from the study might prove helpful for the owner to make better business decisions to improve the survival rate. Furthermore, the owners may utilize available resources to overcome obstacles to become successful. The results of the study may inform policy makers to support small ethnic restaurant businesses. Consequently, small ethnic restaurant business owners may have an opportunity to create employment and support for the communities [5]. Hence, 
the results of the study may not only prove beneficial to the owners but also to the employees and the Canadian society.

\section{A Review of the Professional and Academic Literature}

Assumptions in a study are facts not verified [16]. A number of assumptions impact the study. First, I assumed qualitative case study is an appropriate methodology and design to explore the factors influence the success or failure of small Canadian service businesses. Second, I assumed the businesses are the bounded cases. The clear definition of the case boundaries is a critical requirement for using case study design [17]. Third, I assumed that the interviewees had adequate knowledge of the organization and 1 responded to the questions truthfully and honestly. Fourth, I assumed the responses of the interviewees contained minimal or no personal bias. From the result of the assumptions, the interview data should prove reliable. Fifth, I assumed the small ethnic restaurant businesses in the study represent general small ethnic restaurant businesses across Canada. Sixth, I assumed the classification of Canadian small businesses, which is fewer than 100 employees, according to Industry Canada, is relevant for the study [18].

Small and medium size businesses are important to the national economy [13]. Small business leaders contribute significantly to the job market, economic growth, and innovation [14]. Furthermore, small business leaders contribute to stabilize society and promote regional economic integration [13]. However, Arasti et al. also showed a number of small businesses have failed because of poor performance [13]. As a result, many academic and professional researchers have become interested in understanding the nature of small business. Arasti et al. (2012), Hunter (2011), and Siemens (2010) identified important factors for success and failure including management skills, access to resources, and the environment [3] [13] [19].

\subsection{Small Business in Canada}

Small business is a critical component of many economies including Canada. Gill and Biger noted small businesses are important to the Canadian economy [9]. Most Canadian businesses are small businesses [2], which are the main source of employment for Canadians. As reported by Industry Canada (2013a), a government organization, small business owners employ more than half to the total private labor force [2]. Small firms account for a significant portion of the country's GDP [2]. Furthermore, small business owners are not only operating domestically but also contributing to the country's exports. In 2006 small businesses in the province of British Columbia alone exported $\$ 12$ billion to international markets [9].

The numbers of newly established small businesses every year are significant. In 2012, the number of new small businesses established in Canada was 1.08 million [18]. Although small businesses are an important part of the economy, the 
failure rate among small firms is alarming. Less than one-third of new start up small businesses survives within 10 years [3]. The failure rate is too high, and negatively affects the Canadian economy. Looking at the factors, which make small businesses either succeed or fail, is critical. Management executives and policy makers can improve small business performance by understanding the success or failure factors.

Halabí and Lussier showed if small business owners understand the reasons leading to business success or failure, the failure rate among small businesses may be lower [20]. Small business owners should recognize the factors which might affect the success or failure of the businesses. As a result, the small business owners could make better business decisions to lower the failure rate. Previous literatures on the subject matter of small business performance include both qualitative and quantitative studies. Hunter explored the controllable and uncontrollable factors influence the success of small businesses in Canada using a qualitative approach [3]. In another qualitative study, Miles identified the successful factors for small businesses in the United States in the $21^{\text {st }}$ century [21]. Furthermore, Gill and Biger conducted a quantitative study to examine the relationship between financing, management skills, market situations, regulatory issues and the growth of small businesses using Canadian data [9]. Gill and Biger looked at Canadian small businesses instead of focusing on one group [9]. Thus, past studies do have some limitations.

In general, Hunter (2011), Gill and Biger (2012), and Miles (2013) only provided an overall examination of small businesses [3] [9] [21]. A detailed study of a specific subgroup of small businesses is necessary. One can classify the subgroups by the industry or the characteristics of the owner. Small businesses include different industries such as manufacturing, hospitality, and components and materials [15] [22] [23]. Additionally, one can categorize small businesses into different groups based on the owners' characteristics such as immigrant business owner, female business owner, or Aboriginal business owner [24] [25] [26].

Expanding the study into more and different businesses in various contexts can help to improve the generalization of previous studies. In this study, I provide small business leaders information on the major factors that have an impact on the success of small businesses. Thus, my purpose was to explore how and why some Canadian small businesses have been successful regardless of the limited resources. My focus is on the ethnic restaurant service sector. Understanding the factors that make small businesses succeed or fail is critical for small business leaders [20]. Business leaders might use the findings from the study to improve the business survival rate and future performance. Moreover, government officials may create appropriate economic policies based on the knowledge gained from the study [27]. In addition, I might contribute the results of the study to the body of knowledge on the success and failure factors for small business. 


\subsection{Measurement of Success or Failure}

Defining what success or failure means is important because the purpose of the study is to explore the success or failure factors of small Canadian restaurant businesses. The basic measurement of business success is the ability to survive [28]. However, some other measurements include the firm's revenue or growth, wealth creation, profitability, sustainability, and turnover [29]. Makhbul and Hasun noted several measurements of small business success are the firm's revenue or its growth and profitability [29]. On the other hand, Toledo-López et al. (2012) showed the ability to survive is a critical measurement of success among small businesses [28]. Additionally, Gorgievski, Ascalon, and Stephan (2011) listed 10 criteria for business success. The top four criteria include 1) profitability, 2) growth, 3) innovation, and 4) firm survival or continuity [30].

Regarding small business failure, Hunter defined such failure as discontinuance of ownership or discontinuance of business [3]. The transfer of business ownership because of poor performance is discontinuance of ownership. The other definition, discontinuance of business, includes a cessation in business operations. Lastly, failure is the firm's value is below the opportunity cost of running a business [3]. In addition, Arasti et al. provided some other measures of business failures such as entrepreneurial exit, firm closures, insolvency, dissolution, discontinuance, bankruptcy, and organizational mortality [13].

\subsection{Small Restaurant Service Business}

Small restaurant owners significantly contribute to the job creation and social stabilization [15]. Nevertheless, the restaurant failure rate is high. Ninety percent of new small restaurant business owners fail within the first year of operation [11]. Restaurant business owners share many similar experiences with other small business owners. The reasons for high failure rate include lack of education and training, unable to access formal financial resources, limited management skill, and poor location [11].

\subsubsection{Small Ethnic Restaurants}

Ethnic restaurant owners offer different foods and experience from traditional restaurants of host countries [10]. Moreover, ethnic restaurant owners serve the growing immigrant population. Ethnic restaurants include Italian, Mexican, Chinese, Indian, Korean, and Thai. Sometimes, the consumers perceive Chinese, Italian and Mexican as mainstream foods because of wide availability and familiarity. Customers of ethnic restaurants are well-educated urban professional with above average income [10].

Agarwal and Dahm showed many ethnic restaurants are independent. Independent restaurants are more likely to fail than franchise or chain of restaurants [10]. Franchise restaurant owners usually have more resource, good organization structures, well-known brand, better training and competitive location. Franchise restaurants also have consistent food quality because of using standardize recipes. Customers of independent restaurants usually care more about the ser- 
vice than food quality.

\subsubsection{The Restaurants' and the Owners' Characteristics}

Each restaurant owner has a different motivation to enter the restaurant business. However, pursuing autonomy and living a desirable lifestyle are the main reasons for becoming restaurant business owners in many developed economies such as Canada, the US, Australia, and New Zealand [15]. Some characteristics of the owners affect the restaurant performance such as attitude, expectation, skills, knowledge, control, and ambition. Moreover, male owners of small restaurants are more likely to stay in business and earn more profit than female owners [11].

For the small restaurant business, size and type of operation, competition, and restaurant concept or segment are the main factors contributing to the success or failure of restaurant business owners [11]. Competition in the restaurant business is high and lead to business failure, especially at the downtown location. Agarwal and Dahm shared similar finding in which the high density of restaurant in an area will cause higher failure rate [10]. In addition, the age of the restaurant has an inverse relationship with the failure rate.

Additionally, the ages of the population in the neighborhood area also affect the failure rate of small restaurant businesses [11]. Restaurant failure rate tends to be low in the area where many young adults from 18 to 24 -year-old resides. Also, low-income and middle-income families do support small restaurant businesses. Restaurant in the area with middle and low-income families have the lowest failure rate. Furthermore, restaurant failure rates have a positive relationship with the local unemployment rate [11].

Chen and Elston reported the main contributing factors to the success of the restaurant business include hard work, honesty, and good customer service [15]. Agarwal and Dahm added other successful factors such as good restaurant concept and marketing strategy [10]. However, small restaurant business owners do not have good food-quality control, cannot manage rapid business growth and lack of customer satisfaction [10]. Moreover, most of the business owners have no business plan and lack of financial management knowledge [11]. Work-life balance is important to many successful restaurant owners [10]. However, many restaurant owners failed because of pressure from family, and unable attain work and life balance.

\subsubsection{Experience and Educational Level of the Restaurant Owners}

In general, the educational level of restaurant business owners is low. For example, in China, only 4.6 percent of business owners have some college-level education. Moreover, less than one percent of the owners has formal training in restaurant operations [15]. Regarding work experience, most of the restaurant business owners have worked at another restaurant before starting a restaurant [15]. Both Agarwal and Dahm (2015) and Parsa et al. (2015) showed a direct relationship between the owner education, work experience, and the business per- 
formance [10] [11].

\subsubsection{Accessing Resources for Small Restaurant Business}

Most of the restaurant owners started with small amount of investment. The financial resources mostly come from personal savings, families, and friends. Only 3.8 percent can get loans from financial institutions [15]. Small business owners found difficulty in obtaining a formal bank loan [10]. Restaurant business owners with bank loans are more likely become successful. Larger size restaurants have lower failure rate because the owners have more financial resource and extensive experience. Since restaurant owners have limited resource, accessing high-quality labor is a challenge. Regarding human resource practice, most of the restaurant hire family member [15]. Support from family members is important to the success of small ethnic restaurant [10]. Other uncontrollable factors affecting the success or failure of small restaurant business include economic condition, and government regulation [10].

The main limitation regarding previous research is no case study on small business exists, particularly on the ethnic restaurant service industry in Canada. As a result, in the study, I will fill in the literature gap by conducting a multiple three cases study on small ethnic restaurant service businesses in Canada. The potential finding of the study includes some business owner characteristics as well as internal and external factors. For example, the success of small businesses can come from having adequate resources, good management, and experienced business owners. However, the reasons for business failure include poor management skills in experienced business owners and inadequate resources. Therefore, I can provide suggestions to policy makers to improve business management skills for small business owners and provide the businesses with adequate resources. Thus, the rate of small business success can increase. I can contribute the findings of the study to the body of knowledge on success factors for small businesses in Canada.

\section{Research Methodology}

\subsection{Research Method}

Research method is the way researchers acquire knowledge about the world [31]. Qualitative research was the most appropriate methodology for the study because of the explorative nature of the research question [31]. The quantitative method is to test the relationship among variables by testing hypotheses [32]. However, I did not make any predictions about the factors influence the success of small businesses. Therefore, no hypothesis received testing in the research. Thus, both quantitative and mixed methods were not relevant. The only appropriate methodology for the study was qualitative.

According to Fisher and Stenner, qualitative research is a valuable and legitimate research method, which is gaining respect among scholars [33]. Indeed, researchers use qualitative research to get a generalizable understanding of the 
various aspects of the phenomenon and to answer the how and why questions. An explorative study is relevant because the research question is about an unstructured research problem [34]. The idea is consistent with Thomas and Magilvy, in which qualitative research builds knowledge by exploring a specific phenomenon or experience [35]. Thus, researchers apply qualitative research to gain a deep understanding of the phenomenon or experience [35].

\subsection{Research Design}

Case study was the best choice of design for the study because the purpose of the study is to explore how and why small businesses become successful [17]. Barratt et al. stated case study is an empirical research method, which mainly uses contextually rich data from bounded real-world cases to study a particular phenomenon in detail [36]. In addition, case study design is appropriate for management and organizational studies [37]. De Massis and Kotlar also showed case study is an in-depth study of a contemporary phenomenon within its real-life settings [37]. I collected data from the cases until reaching the data saturation point. I will use interviews, and examination of documents or physical artifacts until saturation occurs. Data saturation point will occur when no new information emerges [13].

\subsection{Population and Sampling}

The population for the study included small ethnic restaurant businesses in British Columbia, Canada. Ethnic restaurant owners provide food from ethnic minority community such as Korean, Indian, or Italian [10]. In the study, I used a purposeful sampling method. I selected three owners of small ethnic restaurant businesses whose businesses have been operating for more than 7 years. Purposeful sampling is a popular sampling method in qualitative research [38]. Researchers use purposeful sampling method to study the cases with rich information content [38]. Palinkas et al. noted the purposeful sampling method is the most effective use of limited resources [38]. The small ethnic restaurant businesses came from the Greater Vancouver Region, British Columbia in Canada. The successful businesses should have existed for more than 7 years under current ownership. Moreover, the businesses should have less than 100 employees to consider small business by Industry Canada [2].

Toledo-López et al. considered the ability to survive as a successful factor for small businesses [28]. Most small businesses failed within 7 years [2]. Thus, I chose the ethnic restaurant businesses that have existed for more than 7 years. Choosing a good number of cases is critical for the study to ensure both validity and detail of analysis [36]. Three cases were reasonable for the study because I could explore the cases in detail and ensure generalization of the study results. Data saturation is the point where new information is just a repetition of previously found information [39]. For most of the qualitative research, five to 30 participants are enough for achieving data saturation [40]. Furthermore, Rowley 
suggested 12 interviews comprise a good number for new researchers [41]. However, in the study, I used multiple data sources, so interviewing three business owners was appropriate to provide enough data.

\subsection{Data Collection Instruments}

$\mathrm{Xu}$ and Storr noted one of the data collection instruments in qualitative research is the researcher [42]. Pezalla, Pettigrew, and Miller-Day, noted that the researcher is the active respondent to collect data in the research process [43]. Therefore, I collected the study data by myself. Connelly stated researchers should carefully develop the research procedure to avoid deception to the research participants [44]. Several ways to collect data for a qualitative study include interviews, observations, focus groups, document analysis, and field notes [45]. Additionally, according to Yin, a researcher can use the following sources of evidence in case study research documentation: archival records, interviews, direct observation, participant observation, and physical artifacts [17].

Furthermore, implementing a triangulation strategy is critical for ensuring the quality of the research [46]. In other words, triangulation is the use of multiple data sources to improve reliability of the data [36]. Two types of triangulation are across-method and within-method [47]. Across method is about having two different methods in a study such as qualitative and quantitative. However, within-method is about having multiple sources of data within a research method. In this study, I used multiple instruments to collect data: the semi-structured interview, exploration of the physical artifacts. I carefully reviewed the research instruments to ensure the reliability and validity of the data collected. During the interview, I asked clarification as needed. Before the research began, I asked for consent from the research participants and then used face-to-face semistructured interviews to collect data. I recorded the interview with the permission of the interviewees. In the next step, I examined some physical artifacts related to the businesses such as menus, websites, or social media pages.

\subsection{Data Collection Technique}

According to Rowley, interview is a popular procedure to collect data for qualitative research [41]. Indeed, researchers use interviews to collect factual data or gain insightful understanding of opinions, attitudes, experiences, processes, behaviours, or predictions. Face-to-face interview is still a dominant way to collect quantitative data [48]. The advantage of face-to-face interviews is researchers can capture the social cues from the interviews [49]. Moreover, from the cues, researchers can develop trust in the interviewees. The social cues include non-verbal communication, voice, intonation, and body language. Therefore, researchers can collect rich information from the interviews [49].

The disadvantages, according to Vogl, are the interviewers may influence the response of the interviewees; thus, interviewer could cause distortions in the interview results [49]. However, being aware of the personal bias is a solution to 
avoid distortion of the interview result [50]. According to Rowley, semi-structured interviews are the most popular with approximately six to 12 prepared questions [41]. Follow up questions is necessary because the interview is semistructured. Compared to an alternative, the questionnaire, interviewing is easier. Moreover, Rowley stated that the researchers do not need to have significant prior knowledge of the topic [41]. In this study, I will explore the unknown factors contribute to the success or failure of small businesses. Thus, interviewing is an appropriate method. Rowley suggested that new researchers should conduct interviews for approximately 30 minutes each [41]. According to Roy et al. (2015), and Yin (2014) three cases should be enough for a multi-case study to reach data saturation [17] [51].

Qualitative interviews is the preference method to collect indepth understanding of the research participant experiences and perspectives [52]. Moreover, semistructured interview is popular among many qualitative researchers [48]. Good interview questions are critical to collect high quality data for the study. The questions should appear well organized and avoid yes or no questions [41]. Therefore, I will ensure the interview questions are open-ended and are able to capture rich quality data before conducting the actual interviews. I will also clarify the response with the research participants during the interview. I will ask the interviewee the prepared questions and follow-up with more relevant questions depending on the participants' answers. Additionally, according to Rowley, a self-introduction and introducing the study is a good practice for the researcher because a good introduction will create a friendly atmosphere for the interview to take place [41].

Merry et al. (2011) and Rowley (2012) indicated researchers must ensure the confidential of the interview data [41] [52]. Furthermore, the researcher must ask for permission to record the interview. In addition, the interviewees have the right to decide whether to answer any specific questions [41]. After the interview, I transcribed the interviews. I ensured the information provided was accurate by using member checking. According to Harvey, member checking is the process of asking the researcher participant to review the response to ensure high quality data. Another term for the same process is member validation [53]. Moreover, by ensuring confidentiality, the interviewee will feel more open to sharing stories. As a result, I can collect useful information for this study.

I implemented data triangulation in this study. Azulai and Rankin suggested data triangulation as a way to improve the quality of research study [46]. I examined the available business physical artifacts including website information. Examination of the physical artifacts is a way to access data, which is not available in the interview [54]. I collected and examined the business physical artifacts if available and use the data in the analysis phase. The multiple data sources may help to improve the quality of the study result [17] [47]. I can look at the cases from multiple dimensions, which ensure a comprehensive understanding of the factors contributing to the business success or failure. Furthermore, such a pro- 
cedure is a cross reference of the collected information and helps to eliminate bias.

\subsection{Data Analysis}

Triangulation means collecting data from multiple sources to ensure consistency in response [17]. Furthermore, triangulation is for eliminating bias and improves the research quality [36] [46]. Yin described four types of triangulation: data triangulation, investigator triangulation, theory triangulation, and methodological triangulation [17]. Within-method triangulation is appropriate in the study in which I collected and analyzed data from multiple data sources: interviews, exploration of the available physical artifacts. For the data analysis phase, first, the recorded interviews received transcribing. I used a computer application to assist me transcribing the interviews. Then, I coded and analyzed the data with the computer software. The coded words then will receive sorting into categories to determine themes [55].

Theme identification is important in a qualitative study [56]. I identified the major themes from the interview data, and the examination of the business physical artifacts. Word repetition is the key to identify the themes. Moreover, I used NVivo ${ }^{\circledR}$ software to help me find the major themes from the collected data. $\mathrm{NVivo}^{\circledR}$ is computer-assisted qualitative data analysis software (CAQDAS) which can help to manage and analyze qualitative data more efficiently [57]. The last step was to write up the findings of the study. Honest and clear representation of the finding is necessary [44]. I compared and contrasted the results and previous literature. I found the links between the findings and the resource-based theory. The resource based theory was a good foundation for the study. I focused on the resourse aspect of the businesses. Usually, business owners with abundent valuable resources are more likely to be successful. Furthermore, from the literature review, the expected key themes can come from the owner characteristics such as business experience and education. Internal factors, that influence the success of small business, include management skill, using mentors, and preparing business plans. External factors are government assistance, the economic environment, and accessing resources. In additional, I tried to match the findings with new literature published after the proposal approved.

\subsection{Reliability and Validity}

\subsubsection{Reliability}

Reliability is about the degree of consistency and repeatability of the measurement [58]. I ensured reliability by using a high quality research instrument by carefully developing the interview questions based on previous literature. I had to develop high quality interview questions to ensure reliability. Another way to improve the reliability of the study is to document all the decisions made in the research process [59]. Furthermore, according to Yin (2014), case study should include triangulation to improve reliability [17]. Triangulation involves the use 
of multiple data sources in a research project. Thus, from the perspective of Jogulu and Pansiri, many researchers use triangulation to strengthen the findings and quality of the research [60]. In this study, I used several sources of data to get an adequate insight of the cases. I interviewed the participants and examine the business physical artifacts to gain an in-depth understanding of the factors contribute to business success or failure to increase the reliability of the study.

\subsubsection{Validity}

According to Drost, with validity, researchers concern the meaningfulness of research components [58]. Validity is an essential criterion when evaluating the quality of the research [61]. The two types of validity are internal and external validity. On the one hand, internal validity is the conditions free of confounding factors. On the other hand, with external validity, Drost (2011) indicated that researchers ensure generalization of the findings [58]. In this study, I used multiple data sources and multiple cases to improve the validity of the findings. A good qualitative study should include the following characteristics: credibility, transferability, dependability, and confirmability [35]. I implemented several strategies to enhance the research quality by improving each component.

\subsubsection{Dependability}

Dependability is close to reliability, which is about the consistency in the research method, design, participation selection, data collection technique, and findings. According to Thomas and Magilvy, dependability occurs when different researchers can follow the same decision trail used in the research [35]. Triangulation is another way to enhance dependability [61]. During the interview, I used member checking to improve the reliability and validity of the data, a method to confirm information with the research participants [53].

\subsubsection{Credibility}

Credibility is similar to internal validity. Wester stated researchers use credibility to ensure the study results show the truth [62]. In other words, credibility is about an actual representation of what happens in real world situations. Appropriate sample size, field notes, and audit trail are several factors influencing credibility [62]. Moreover, investigator triangulation such as member checking or peer review is methods to increase credibility [46]. Looking for similar themes in various interview transcripts is a way to ensure credibility [35]. In this study, to ensure credibility, I used member checking to make sure the collected data meet the four characteristics of credibility, transferability, dependability, and confirmability.

\subsubsection{Transferability}

Transferability is similar to external validity. Thomas and Magilvy stated transferability mean research findings should hold truth in different locations or businesses [35]. I described the context and assumptions regarding the research process to enhance transferability. Triangulation is a method helps to improve 
research validity. Moreover, I ensured data saturation in the research process. O'Reilly and Parker indicated that data saturation happens when the collected information has achieved both depth and breadth [63]. Dworkin stated, for qualitative research, data saturation is obtainable with five to 30 participants [40]. Roy et al. stated three cases are enough for a multi-case study research [51]. Data saturation is necessary to improve the generalizability of the research. At the data saturation point, information is redundant or repetition of previously collected data [64]. Thus, I can ensure data saturation by having three cases.

\subsubsection{Confirmability}

Houghton et al. noted a study with accurate and neutral data has confirmability [65]. I ensured confirmability by using audit trail and reflexivity strategies. Audit trail is about making note of all the decision and judgment along the research process. Qualitative researchers should pay attention to the personal interest and history to ensure reflexivity. A reflective diary, which includes documentation of decisions during the research process, is necessary to ensure confirmability [65]. Moreover, a qualitative study possesses all other three characteristics: credibility, transferability, and dependability have conformability [35]. I will need to provide a detailed field note of the research process so other can confirm the result.

\section{Findings}

The findings of the study included five main themes for the successful factors of small ethnic restaurant business owners 1) hard work, 2) interest or passion, 3) family support, 4) location, and 5) food and service quality. First, all participants mentioned hard working. Working hard is the most critical factor according to the restaurant owners. Second, three participants stated that passion or interest also contributed to their success. The owners' passion or interest in the business keeps them away from giving up in the first few years of operation. Third, the business owners emphasized the importance of having family support. Family members can provide labor as the backup to the business. Fourth, $67 \%$ owners stated the location is a critical role in the business success. Through an exploration of the restaurant's location, I can confirm the location factor. Fifth, the quality of food and services is also important for the restaurant businesses. My examination of customers' feedback on the restaurant websites and social media pages revealed the majority of customers like the restaurant because of the quality of the food and service. In this section, I will present a detailed analysis of each theme. Table 1 below includes demographic information regarding the restaurants and the owners.

For the interviews, open-ended questions were used to gather insightful information from the restaurant owners [41]. Since the interviews were semi-structured, I asked additional questions based on the participants' response. During the interview, I used member checking to confirm the participants' answers to improve the collected data quality. I recorded, transcribed, and analyzed the interviews. I 
Table 1. Demographic information about the restaurants and the owners.

\begin{tabular}{ccccc}
\hline & Characteristics & Case 1 & Case 2 & Case 3 \\
\hline The Owner & Acronym & P1 & P2 & P3 \\
& Gender & Male & Male & Female \\
& Age & 39 & 53 & 40 \\
& Educational Level & High School & High School & College \\
& Ethnicity & Indian & Indian & Vietnamese \\
& Native Language & Hindi & Punjabi & Vietnamese \\
& Business experience & 16 years & 23 years & 18 years \\
& Type of food & Indian & Greek, Italian, Indian & Vietnamese \\
The Restaurant & Current ownership & 10 years & 11 years & 8 years \\
& No. of Employee & 16 & 8 to 11 & 11 \\
\hline
\end{tabular}

used pen and paper to code the transcripts to find themes. I also examined some physical artifacts of the business such as websites, social media pages, menus, and the restaurants.

All data collected for this research are confidential. Collected data is maintaned in a locked storage, and electronic data is secured via a password protected folder on a personal computer and cloud drive. After 5 years, I will destroy all data. To ensure high quality of the research, I used triangulation. Two types of data triangulation are across method and within-method [47]. In this study, I used multiple cases, multiple data sources, interviews, and examination of the business physical artifacts. Yin stated researchers using triangulation could improve the reliability and validity of the research study [17].

After analyzing the collected data, which included the interview transcripts and the physical artifacts, I identified five distinctive themes: 1) hard work, 2) interest or passion, 3) family support, 4) location, and 5) foods and services quality. I will discuss each theme in the following sub-sections.

\subsection{Theme 1: Hard Work}

Hard work was the first factor that came out of $3 / 3$ (100\%) participants' minds. In the RBV, business owners create competitive advantages from using their resources [66]. However, the small ethnic restaurant owners have fewer resources compare to large businesses. Inadequate resource limits the business performance [67] [68]. To compensate the limited resources, business owners have to work hard and perform multiple tasks. This theme confirmed the findings by Aguilar-Morales et al. (2013), and Renko et al. (2012) showing that successful small business owners work hard [69] [70].

\subsection{Theme 2: Interest or Passion}

Interest or passions are critical factors that keep the owners in the business. To remain successful, the owners have to love what they are doing. For example, 
when I asked P2 “... so, you like Greek foods?” He replied, "Not like, I love it.” The business owners get motivation from their interest or passion. According to P3, the first few years of operation was challenging since there was low and unstable income. Gomezelj and Kušce indicated that a business is not usually profitable in the first few years of operation [27]. Thus, financial risks are associated with the new businesses. However, the restaurant owners with passion for their businesses can avoid giving up. Furthermore, Alam et al. suggested commitment to the business, which derives from the owners' interest or passion, contributes significantly to make the business successful [71]. Similarly, P1 stated, whatever people do, they have to be serious and have an interest in it. As stated in the $\mathrm{RBV}$, passion, or interest is a valuable intangible resource that the business owners possess [66].

\subsection{Theme 3: Family Support}

All the restaurant owners (3/3 100\%) in this study received tremendous support from their families. Families provide a trustable human resource instead of financial support to the business owners. Chen and Elston stated most small restaurant owners hire family members [15]. P1 often calls family members for help during a labor shortage. Additionally, P1 usually consults the spouse when making important business decisions. Agarwal and Dahm stated similar finding which family support is critical for small restaurant businesses [10]. P2 bought the restaurant from his/her brother. P2's brother started the restaurant, and P2 worked for him for many years before taking over the restaurant. P2 stated learned a lot from working with his/her brother. Currently, P2's brother owns another restaurant and can provide P2 support and advice when needed. Additionally, P3 mentioned that many family members are currently working in the restaurant. Small business owners found it hard to access qualified external human capital because of their limited resource [72]. Applying the RBV, family is a valuable resource because family members can help to improve the business effectiveness and efficiency [73].

\subsection{Theme 4: Location}

Location is a critical factor that contributes to the success of the restaurant businesses. As reported by Parsa et al., many small business owners fail because of having a poor location choice [11]. Agarwal and Dahm found a similar result that small independent restaurants are more likely to obtain success if they have a competitive location [10]. Furthermore, location can be a unique resource which the owners can use to create competitive advantages according to Penrose's Resource Based View (RBV) [74]. From the interview, P1 and P3 mentioned the importance of having a good location. All three businesses in this study are on the major streets in their cities. P1's and P2's restaurants are close to the sky-train station, a large shopping mall, and business center. In addition, a campus of a major university, many small colleges, office buildings, and residen- 
tial areas surround the businesses. P3's restaurant is close to an amusement park and arena where many seasonal events and summer fairs take place. P3 indicated the location helps to create a competitive advantage for the business since events almost every weekend at the park. Furthermore, good walking traffic exists around the restaurant.

\subsection{Theme 5: Food and Service Quality}

Through the examination of the business websites, social media pages, and restaurant directory sites such as Zomato and Yelp, I found food and service quality are significant to the success of the businesses. Many customers gave the restaurants high rating because the foods are tasty, or the staff is attentive. Furthermore, many customers indicated that they would like to come back in the future, some of them referred the restaurant to their friends, and some of them were referred by other customers. The customers of P1's restaurant stated the servers were friendly and helpful. Moreover, a customer commented that the restaurant is willing to customize the meals to meet the customer preferences. A customer of P2's restaurant said that a colleague at work referred her to the restaurant. P2's customer loves the restaurant because of the tasty foods. For P3's restaurant, the customers commented that food and service quality are consistent. The price is also reasonable for quick and efficient services. The findings are consistent with past literature. Agarwal and Dahm showed that consistency in the food and service quality can contribute to the restaurant success [10]. Moreover, the theme of food and service quality is consistent with the RBV, in which ability to provide decent food and service is an intangible resource for the business [74].

\section{Discussion}

The result of the study might prove valuable to current and future owners of ethnic restaurant businesses. Business owners can improve their business performance by applying knowledge from this study. The study findings include five distinctive themes: 1) hard work, 2) interest or passion, 3) family support, 4) location, and 5) foods and services quality. Moreover, the information can help small business leaders avoid potential barriers and know how to approach the barriers in an effective way. In the RBV, business owners should utilize tangible and intangible resources to create competitive advantages [75]. However, small businesses usually do not have access to many resources comparing to larger businesses [16]. Thus, small businesses have a higher chance of failure [3]. The result of this study reveals five key factors contributing to business success. Future and current small business owners could learn from the study results to improve their business performance. The small ethnic restaurant owners can improve their business survival rate by applying the success factors in the business. Although all restaurant owners in this study are immigrant, they can still become successful by applying these factors.

The result of this study could help to improve the performance and survival 
rate of the small ethnic restaurant business. Small business is a critical component of the national economy [1]. Therefore, if the survival rate of the small business increases, the business owners can contribute significantly to the GDP, and national employment [2]. Lack of knowledge of the appropriate strategies can cause high business failure. The results of the study may help to fill in the gap of knowledge of what strategies influence the business success. Small business owners can now understand and apply the new strategies to improve business performance. The study result could prove valuable to policy makers. Indeed, government policy makers can help to improve small business survival rate by providing support to small businesses such as human resources or management training. Improving small business survival rate could help society avoid wasting resource and become more effective and efficient.

From this study, the owners of ethnic restaurant businesses can take several actions to improve their performance and survival rate. The business owners need to understand five factors that influence their success: 1) hard work, 2) interest or passion, 3) family support, 4) location, and 5) foods and services quality. The study result includes current and future business owners a checklist of the factors that can follow. First, small business owners should work hard and have a serious attitude regarding the businesses. Second, the business owners should have passion and interest in what they are doing because those factors can help owners overcome potential obstacles, and difficult situation. A strong passion and interest prevent owners from giving up, allow them to accept challenges and strive for success. Therefore, an important question to ask before starting an ethnic restaurant business is: Do I really have interest or passion in the type of business that I am going to establish? The passion enables small business owners to overcome the hardship in first few years of operation when financial risks are with newly started businesses [27]. Third, business owners should ensure they have someone such as family members or friends who are supportive and can provide help. Family support is especially important when the business first establish. Ahmad stated new small business owners do not have adequate resources to hire external human resources [72]. Family members usually provide cost effective labor support to the small business; thus, many small restaurant business owners hire their family members [15]. Fourth, the future business owners should choose a good location to start up their business. Good location can improve the chance of having business success [11]. Fifth, exceptional food and service quality can make the customer happy; thus, improve the business performance [10]. My intention is to publish the case study in ProQuest and take advantage of opportunities to share findings with owners and managers in the ethnic food industry, colleges and universities, and forums where business leaders discuss strategies for business survival.

I conducted a qualitative multi-case study on the successful factors for small ethnic restaurant businesses. The study consists of three cases in the Greater Vancouver, British Columbia Canada. The small size is one of the limitations in this study. Moreover, the study was limited to one geographic location. There- 
fore, to generalize the findings, future researchers can expand to different geographic locations such as different provinces, or countries. This research was in the urban areas; other research can choose population in the suburb areas. Moreover, a future researcher can look at different segments of the food and service industry such as coffee shops, restaurant chains, or take-out restaurants. Even broader, future researchers can choose different types of small businesses in the other industries such as retail, manufacturing, or other services. Additionally, future researchers can use quantitative research to test the variables found from this study (five themes) on a larger set of data. Future quantitative researchers can develop a hypothesis to test the relationships between variables and the business performance such as financial performance. As a result, the scholar community can better generalize findings from this research.

\section{Conclusions}

Small business owners contribute significantly to the national economy; however, many of them face high failure rate [2]. The purpose of this multi-case study was to determine the factors that contribute to the success of small ethnic restaurants businesses. Three owners of small ethnic restaurants in Greater Vancouver, British Columbia were invited in this study. The author used a semi-structured interview technique and examined physical artifacts including the business location, premises, websites, social media pages, and the online restaurant directories. Five key factors, which influence the business success were identified 1) hard work, 2) interest or passion, 3) family support, 4) location, and 5) foods and services quality. By understanding the importance of those factors, current and future owners of small ethnic restaurants can improve their business strategies and performance. Owners of small businesses in general can use these findings to increase their survival rate, thus contributing positively to employment rate as well as the national GDP [2]. As a recommendation for future research, future researchers can expand the study to different types of small restaurant business at large and at different locations.

Limitations are the potential weaknesses of the study [76]. The main limitation is the inability to generalize the finding because of two reasons. First, the number of cases is small. Second, the geographic location of the study is only in British Columbia. The study contains only three cases in British Columbia making generalizability impossible. Another limitation could include the biases in the response of the research participants.

Delimitations of the study involve the sizes of the organization, the geographic location of the study, and the sector of the industry. First, I only focused the study on ethnic restaurant businesses because my purpose is to explore the factors that influence the success or failure of small ethnic restaurant businesses. Second, I only included small size ethnic restaurants. Small businesses are businesses with fewer than 100 employees [77]. Larger size businesses are not in the study. Third, the geographic location of the study is limited to British Columbia in Canada. 


\section{Conflicts of Interest}

The authors declare no conflicts of interest regarding the publication of this paper.

\section{References}

[1] Chandler, V. (2012) The Economic Impact of the Canada Small Business Financing Program. Small Business Economics, 39, 253-264. https://doi.org/10.1007/s11187-010-9302-7

[2] Industry Canada (2013) Key Small Business Statistics. Industry Canada, Small Business Branch.

[3] Hunter, M.G. (2011) Understanding the Common Causes of Small Business Failures: A Qualitative Study. Journal of Applied Management and Entrepreneurship, 16, 86-103.

[4] Macdonald, R., Statistics Canada, Economic Analysis Division (2012) Firm Dynamics the Death of New Canadian Firms: A Survival Analysis of the 2002 Cohort of Entrants to the Business Sector. Statistics Canada, Economic Analysis Division, Ottawa.

[5] Ruddy, A., Kastelen, K. and English, J. (2014) Wanted: Government Vision for Small Business.

[6] Troster, N. (2011) Perspectives on Small Business in Canada. Canadian Federation of Independent Business, Toronto.

[7] de la Garza Carranza, M.T. and Egri, C.P. (2010) Managerial Cultural Intelligence and Small Business in Canada. Management Revue, 21, 353-371.

https://doi.org/10.5771/0935-9915-2010-3-353

[8] Barbero, J.L., Casillas, J.C. and Feldman, H.D. (2011) Managerial Capabilities and Paths to Growth as Determinants of High-Growth Small and Medium-Sized Enterprises. International Small Business Journal, 29, 671-694. https://doi.org/10.1177/0266242610378287

[9] Gill, A. and Biger, N. (2012) Barriers to Small Business Growth in Canada. Journal of Small Business and Enterprise Development, 19, 656-668. https://doi.org/10.1108/14626001211277451

[10] Agarwal, R. and Dahm, M.J. (2015) Success Factors in Independent Ethnic Restaurants. Journal of Foodservice Business Research, 18, 20-33. https://doi.org/10.1080/15378020.2015.995749

[11] Parsa, H.G., Rest, J.-P.I., Smith, S.R., Parsa, R.A. and Bujisic, M. (2015) Why Restaurants Fail? Part IV. The Relationship between Restaurant Failures and Demographic Factors. Cornell Hospitality Quarterly, 56, 80-90. https://doi.org/10.1177/1938965514551959

[12] Lyons, B. (2012) Canadian Macroeconomics: Problems \& Policies. 10th Edition, Pearson Prentice Hall, Toronto.

[13] Arasti, Z., Zandi, F. and Talebi, K. (2012) Exploring the Effect of Individual Factors on Business Failure in Iranian New Established Small Businesses. International Business Research, 5, 2-6. https://doi.org/10.5539/ibr.v5n4p2

[14] Teng, H.S.S., Bhatia, G.S. and Anwar, S. (2011) A Success versus Failure Prediction Model for Small Businesses in Singapore. American Journal of Business, 26, 50-64. https://doi.org/10.1108/19355181111124106

[15] Chen, S.C. and Elston, J.A. (2013) Entrepreneurial Motives and Characteristics: An 
Analysis of Small Restaurant Owners. International Journal of Hospitality Management, 35, 294-305. https://doi.org/10.1016/j.ijhm.2013.07.002

[16] Knight, S. and Cross, D. (2012) Using Contextual Constructs Model to Frame Doctoral Research Methodology. International Journal of Doctoral Studies, 7, 39-62. https://doi.org/10.28945/1559

[17] Yin, R.K. (2014) Case Study Research: Design and Methods. 5th Edition, SAGE Publications, Inc., Los Angeles.

[18] Industry Canada (2013) The Canadian Provinces-September 2013-SME Research and Statistics.

[19] Siemens, L. (2010) Challenges, Responses and Available Resources: Success in Rural Small Businesses. Journal of Small Business and Entrepreneurship, 23, 65-80. https://doi.org/10.1080/08276331.2010.10593474

[20] Halabí, C.E. and Lussier, R.N. (2014) A Model for Predicting Small Firm Performance: Increasing the Probability of Entrepreneurial Success in Chile. Journal of Small Business and Enterprise Development, 21, 4-25. https://doi.org/10.1108/JSBED-10-2013-0141

[21] Miles, K.J. (2013) Exploring Factors Required for Small Business Success in the 21st Century. Walden University, Minneapolis.

[22] Kang, S.-W. (2012) An Identification of Unsuccessful, Failure Factors of Technology Innovation and Development in SMEs: A Case Study of Components and Material Industry. International Journal of Business and Management, 7, 16-30. https://doi.org/10.5539/ijbm.v7n19p16

[23] Mohiuddin, M. and Su, Z. (2013) Manufacturing Small and Medium Size Enterprise's Offshore Outsourcing and Competitive Advantage: An Exploratory Study on Canadian Offshoring Manufacturing SMEs. Journal of Applied Business Research, 29, 1111-1130. https://doi.org/10.19030/jabr.v29i4.7920

[24] Foley, D. and O'Connor, A.J. (2013) Social Capital and the Networking Practices of Indigenous Entrepreneurs. Journal of Small Business Management, 51, 276-296. https://doi.org/10.1111/jsbm.12017

[25] Robb, A.M. and Watson, J. (2012) Gender Differences in Firm Performance: Evidence from New Ventures in the United States. Journal of Business Venturing, 27, 544-558. https://doi.org/10.1016/j.jbusvent.2011.10.002

[26] de Vries, H.P. (2012) Do Indian Immigrant Entrepreneurs Residing in Different Host Countries Display the Same Behavioural Patterns? Journal of Enterprising Communities: People and Places in the Global Economy, 6, 138-153. https://doi.org/10.1108/17506201211228949

[27] Gomezelj, D.O. and Kušce, I. (2013) The Influence of Personal and Environmental Factors on Entrepreneurs' Performance. Kybernetes, 42, 906-927. https://doi.org/10.1108/K-08-2012-0024

[28] Toledo-López, A., Díaz-Pichardo, R., Jiménez-Castañeda, J.C. and Sánchez-Medina, P.S. (2012) Defining Success in Subsistence Businesses. Journal of Business Research, 65, 1658-1664. https://doi.org/10.1016/j.jbusres.2012.02.006

[29] Makhbul, Z.M. and Hasun, F.M. (2011) Entrepreneurial Success: An Exploratory Study among Entrepreneurs. International Journal of Business and Management, $\mathbf{6}$, 116-125. https://doi.org/10.5539/ijbm.v6n1p116

[30] Gorgievski, M.J., Ascalon, M.E. and Stephan, U. (2011) Small Business Owners' Success Criteria, a Values Approach to Personal Differences. Journal of Small Business Management, 49, 207-232. https://doi.org/10.1111/j.1540-627X.2011.00322.x 
[31] Khan, S.N. (2014) Qualitative Research Method-Phenomenology. Asian Social Science, 10, 298-310. https://doi.org/10.5539/ass.v10n21p298

[32] Balkin, R.S. (2014) Principles of Quantitative Research in Counseling: A Humanistic Perspective. The Journal of Humanistic Counseling, 53, 240-248. https://doi.org/10.1002/j.2161-1939.2014.00059.x

[33] Fisher Jr., W.P. and Stenner, A.J. (2011) Integrating Qualitative and Quantitative Research Approaches via the Phenomenological Method. International Journal of Multiple Research Approaches, 5, 89-103. https://doi.org/10.5172/mra.2011.5.1.89

[34] Ghauri, P. and Gronhaug, K. (2010) Research Methods in Business Studies. 4th Edition, Financial Times Prentice Hall, Harlow.

[35] Thomas, E. and Magilvy, J.K. (2011) Qualitative Rigor or Research Validity in Qualitative Research. Journal for Specialists in Pediatric Nursing, 16, 151-155. https://doi.org/10.1111/j.1744-6155.2011.00283.x

[36] Barratt, M., Choi, T.Y. and Li, M. (2011) Qualitative Case Studies in Operations Management: Trends, Research Outcomes, and Future Research Implications. Journal of Operations Management, 29, 329-342. https://doi.org/10.1016/j.jom.2010.06.002

[37] De Massis, A. and Kotlar, J. (2014) The Case Study Method in Family Business Research: Guidelines for Qualitative Scholarship. Journal of Family Business Strategy, 5, 15-29. https://doi.org/10.1016/j.jfbs.2014.01.007

[38] Palinkas, L.A., Horwitz, S.M., Green, C.A., Wisdom, J.P., Duan, N. and Hoagwood, K. (2013) Purposeful Sampling for Qualitative Data Collection and Analysis in Mixed Method Implementation Research. Administration and Policy in Mental Health, 42, 533-544. https://doi.org/10.1007/s10488-013-0528-y

[39] Kolb, S.M. (2012) Grounded Theory and the Constant Comparative Method: Valid Research Strategies for Educators. Journal of Emerging Trends in Educational Research and Policy Studies, 3, 83-86.

[40] Dworkin, S.L. (2012) Sample Size Policy for Qualitative Studies Using In-Depth Interviews. Archives of Sexual Behavior, 41, 1319-1320. https://doi.org/10.1007/s10508-012-0016-6

[41] Rowley, J. (2012) Conducting Research Interviews. Management Research Review, 35, 260-271. https://doi.org/10.1108/01409171211210154

[42] Xu, M.A. and Storr, G.B. (2012) Learning the Concept of Researcher as Instrument in Qualitative Research. The Qualitative Report, 17, 1-18.

[43] Pezalla, A.E., Pettigrew, J. and Miller-Day, M. (2012) Researching the Researcher-as-Instrument: An Exercise in Interviewer Self-Reflexivity. Qualitative Research, 12, 165-185. https://doi.org/10.1177/1468794111422107

[44] Connelly, L.M. (2014) Ethical Considerations in Research Studies. MEDSURG Nursing, 23, 54-55.

[45] Parylo, O. (2012) Qualitative, Quantitative, or Mixed Methods: An Analysis of Research Design in Articles on Principal Professional Development (1998-2008). International Journal of Multiple Research Approaches, 6, 297-313. https://doi.org/10.5172/mra.2012.6.3.297

[46] Azulai, A. and Rankin, J.A. (2012) Triangulation in Canadian Doctoral Dissertations on Aging. International Journal of Multiple Research Approaches, 6, 125-140. https://doi.org/10.5172/mra.2012.6.2.125

[47] Bekhet, A.K. and Zauszniewski, J.A. (2012) Methodological Triangulation: An Approach to Understanding Data. Nurse Researcher, 20, 40-43. 
https://doi.org/10.7748/nr2012.11.20.2.40.c9442

[48] Deakin, H. and Wakefield, K. (2014) Skype Interviewing: Reflections of Two PhD Researchers. Qualitative Research, 14, 603-616. https://doi.org/10.1177/1468794113488126

[49] Vogl, S. (2013) Telephone versus Face-to-Face Interviews Mode Effect on Semi-Structured Interviews with Children. Sociological Methodology, 43, 133-177. https://doi.org/10.1177/0081175012465967

[50] Opdenakker, R. (2006) Advantages and Disadvantages of Four Interview Techniques in Qualitative Research. Forum: Qualitative Social Research, 7, Article 11.

[51] Roy, K., Zvonkovic, A., Goldberg, A., Sharp, E. and LaRossa, R. (2015) Sampling Richness and Qualitative Integrity: Challenges for Research with Families. Journal of Marriage and Family, 77, 243-260. https://doi.org/10.1111/jomf.12147

[52] Merry, L., Clausen, C., Gagnon, A.J., Carnevale, F., Jeannotte, J., Saucier, J.-F., et al. (2011) Improving Qualitative Interviews with Newly Arrived Migrant Women. Qualitative Health Research, 21, 976-986. https://doi.org/10.1177/1049732311403497

[53] Harvey, L. (2015) Beyond Member-Checking: A Dialogic Approach to the Research Interview. International Journal of Research \& Method in Education, 38, 23-38. https://doi.org/10.1080/1743727X.2014.914487

[54] Malagon-Maldonado, G. (2014) Qualitative Research in Health Design. Herd, 7, 120-134. https://doi.org/10.1177/193758671400700411

[55] Pierre, E.A.S. and Jackson, A.Y. (2014) Qualitative Data Analysis after Coding. Qualitative Inquiry, 20, 715-719. https://doi.org/10.1177/1077800414532435

[56] Conboy, K., Fitzgerald, G. and Mathiassen, L. (2012) Qualitative Methods Research in Information Systems: Motivations, Themes, and Contributions. European Journal of Information Systems, 21, 113-118. https://doi.org/10.1057/ejis.2011.57

[57] Sinkovics, R.R. and Alfoldi, E.A. (2012) Progressive Focusing and Trustworthiness in Qualitative Research: The Enabling Role of Computer-Assisted Qualitative Data Analysis Software (CAQDAS). Management International Review, 52, 817-845. https://doi.org/10.1007/s11575-012-0140-5

[58] Drost, E.A. (2011) Validity and Reliability in Social Science Research. Education, Research and Perspectives, 38, 105.

[59] Grossoehme, D.H. (2014) Overview of Qualitative Research. Journal of Health Care Chaplaincy, 20, 109-122. https://doi.org/10.1080/08854726.2014.925660

[60] Jogulu, U.D. and Pansiri, J. (2011) Mixed Methods: A Research Design for Management Doctoral Dissertations. Management Research Review, 34, 687-701. https://doi.org/10.1108/01409171111136211

[61] Zohrabi, M. (2013) Mixed Method Research: Instruments, Validity, Reliability and Reporting Findings. Theory \& Practice in Language Studies, 3, 254-262. https://doi.org/10.4304/tpls.3.2.254-262

[62] Wester, K.L. (2011) Publishing Ethical Research: A Step-by-Step Overview. Journal of Counseling \& Development, 89, 301-307. https://doi.org/10.1002/j.1556-6678.2011.tb00093.x

[63] O'Reilly, M. and Parker, N. (2013) “Unsatisfactory Saturation": A Critical Exploration of the Notion of Saturated Sample Sizes in. Qualitative Research, 13, 190-197. https://doi.org/10.1177/1468794112446106

[64] Marshall, B., Cardon, P., Poddar, A. and Fontenot, R. (2013) Does Sample Size Matter in Qualitative Research? A Review of Qualitative Interviews in Is Research. 
Journal of Computer Information Systems, 54, 11-22. https://doi.org/10.1080/08874417.2013.11645667

[65] Houghton, C., Casey, D., Shaw, D. and Murphy, K. (2013) Rigour in Qualitative Case-Study Research. Nurse Researcher, 20, 12-17. https://doi.org/10.7748/nr2013.03.20.4.12.e326

[66] Perrigot, R. and Pénard, T. (2013) Determinants of E-Commerce Strategy in Franchising: A Resource-Based View. International Journal of Electronic Commerce, 17, 109-130. https://doi.org/10.2753/JEC1086-4415170305

[67] Keen, C. and Etemad, H. (2012) Rapid Growth and Rapid Internationalization: The Case of Smaller Enterprises from Canada. Management Decision, 50, 569-590. https://doi.org/10.1108/00251741211220138

[68] Thomason, S.J., Simendinger, E. and Kiernan, D. (2013) Several Determinants of Successful Coopetition in Small Business. Journal of Small Business and Entrepreneurship, 26, 15-28. https://doi.org/10.1080/08276331.2012.761800

[69] Aguilar-Morales, N., Sandoval-Caraveo, M., Del, C., Surdez-Pérez, E.G. and Gómez-Jiménez, S.G. (2013) Characteristics of Entrepreneurs of Small Business in Tabasco, Mexico. Review of Business \& Finance Studies, 4, 23-36.

[70] Renko, M., Kroeck, K.G. and Bullough, A. (2012) Expectancy Theory and Nascent Entrepreneurship. Small Business Economics, 39, 667-684. https://doi.org/10.1007/s11187-011-9354-3

[71] Alam, S.S., Jani, M.F.M. and Omar, N.A. (2011) An Empirical Study of Success Factors of Women Entrepreneurs in Southern Region in Malaysia. International Journal of Economics and Finance, 3, 166-175. https://doi.org/10.5539/ijef.v3n2p166

[72] Ahmad, S.Z. (2012) Micro, Small and Medium-Sized Enterprises Development in the Kingdom of Saudi Arabia. World Journal of Entrepreneurship, Management and Sustainable Development, 8, 217-232. https://doi.org/10.1108/20425961211276606

[73] Seshadri, S. (2013) Sourcing Competence in Design and Development Collaboration: A Resource Based View. Asia Pacific Management Review, 18, 323-344.

[74] Lockett, A. and Wild, A. (2014) Bringing History (Back) into the Resource-Based View. Business History, 56, 372-390. https://doi.org/10.1080/00076791.2013.790371

[75] Jacobsen, L. (2013) On Robinson, Penrose, and the Resource-Based View. The European Journal of the History of Economic Thought, 20, 125-147. https://doi.org/10.1080/09672567.2011.565355

[76] Connelly, L.M. (2013) Limitation Section. MEDSURG Nursing, 22, 325-336.

[77] Alsaaty, F.M. (2011) A Model for Building Innovation Capabilities in Small Entrepreneurial Firms. Academy of Entrepreneurship Journal, 17, 1-21. 